\title{
Challenges Encountered by Scientific Searchers in Cote D'Ivoire
}

\author{
Sylla Mamadou ${ }^{1} \&$ Grafoute Amoro $^{1}$ \\ ${ }^{1}$ Associates Professors and researchers at the Faculty of Economics and Management, Félix Houphouët-Boigny \\ University Abidjan, Cocody, Cote D'Ivoire \\ Correspondence: Sylla Mamadou, Associate Professor and researcher at the Faculty of Economics and \\ Management, Félix Houphouët-Boigny University Abidjan, Cocody, Cote D'Ivoire. E-mail: \\ gralaoda@hotmail.com
}

Received: May 21, 2019

Accepted: June 16, 2019

Online Published: August 5, 2019

doi:10.5539/ijbm.v14n9p114

URL: https://doi.org/10.5539/ijbm.v14n9p114

\begin{abstract}
This study is a survey from differences Universities of Cote d'ivoire, in order to understand the challenges facing by searchers during their scientific research. The study developed questionnaire consisting of five hypotheses, among diversities of challenges encountered by scientific searchers around the World. The choice of this five hypothesis is due to the differences characteristics such as the history of the nations and because Cote d'ivoire is less-developed country. This paper adopted a qualitative and quantitative analysis research strategy to examine the difficulties facing by searchers. This Work used two methods a semi -structured interview, and experimentation. Qualitative data has been collected through interview while quantitative data by experimentation.

Our finding confirmed the difficulty encountered by the differences searchers at Universities or institutions searchers, or institutions searchers to achieve a fruitful outcomes research for its own interest or for participation in country development projects.
\end{abstract}

Keywords: challenges, scientific research, Cote d'Ivoire

\section{Introduction}

Scientific research is a common methodology elaborated by searchers at Universities or institutions. It is a new knowledge through an independent information. The work of searcher is to recoup information through different channels information or website. He expected to elaborate a new knowledge, or to confirm a previous empirical work result. Or may be bring an amendment of existing knowledge. In addition to learning about the scientific work, self-governed work on the assignment is seen as an approach to developing skills (See e.g. Limberg, 1999; Smith \& Hepworth 2007; Wallace, Kupperman, Krajcik, \& Soloway 2000). Although Scientific research allow a searchers to be cognized and enhance its performance in differences field, it is also allow him to learn and understand the research environments. His research result will use or amended by other searchers through reflection and criticism in open sites.

Today intellectual or universities searchers from different countries debate researches results. However, in Africa, searchers contributed less in world creation of knowledge. The reason is that most of African countries still under developed with inefficiency infrastructure on education field. The research as we know is the starting point of scientific projects, which enhance human capital and development of the nation .Research, is also significant determinant of country productivity (GDP).

In Cote d'Ivoire, although research ranked a predominant choice, the budget allocate in the education system for research still insignificant, with a little investment in research. For example, in 2011, when worldwide expenditure on research was $1.77 \%$ of the total global gross domestic product, Cote divoire spent $0.2 \%$ of its GDP and South Africa spent $0.76 \%$ of its GDP-on research. The investment in research continues to be down and as consequences the African continent are facing deterioration of human capital and diseases may continue to resurface with depreciation of living standard, death rates multiplied with a short expectancy. Those mentioned above are the lack of will of leader to give priority on scientific research. Debating about the difficulties to conducting scientific research in Cote d'Ivoire is a step towards contributing of the existing finding and identifying all parameters affecting the scientific research in the country which will could alleviate the differences difficulties facing by the countries, in term of challenges to come to the development. 
Located in West Africa, cote d'ivoire still since the independence, a less-developed country, where the scientific research Works till a challenge to achieve a good development projects. For instance the tendency of cote d'ivoire expenditure in education area From 1970 to 2015, has been evidenced by University of sherbrooke quebec, Canada. We found that large expenditure was the period of 1979 called « Miracle ivoirien » it is the prosperity period in which the cote d'ivoire started to build its infrastructure, in term of education. But from 1990 the share of GDP allocate in the education system became low due to the budget deficit leads by the decline of export revenue. .

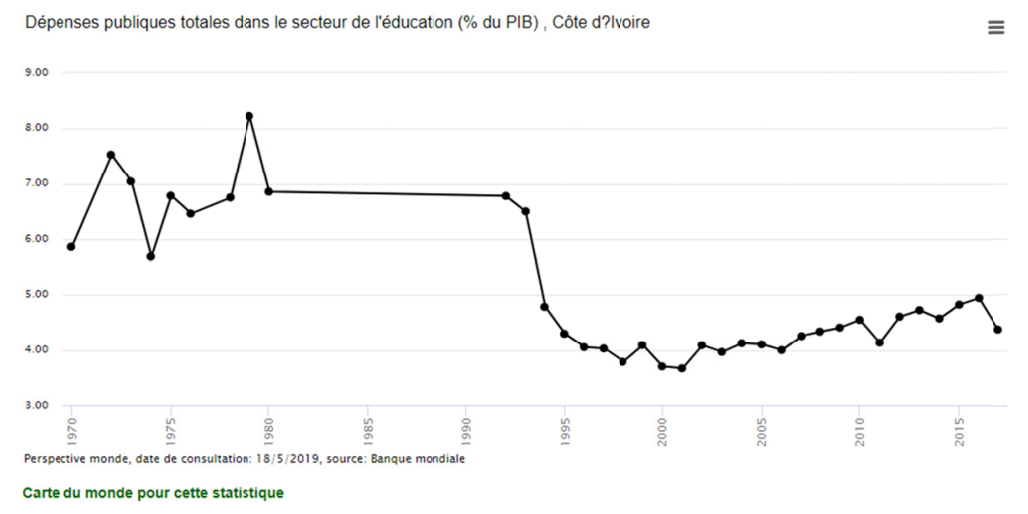

Figure 1. Tendency of expenditure in education area (\%GDP) from 1970 to 2015

This paper has purpose to find out the challenges that searchers face during their research papers. We will examine challenges encountered by searchers in Cote d'ivoire. The findings of this study will be instrumental in identifying opportunities for improvement, as well as elements that need to be factored into the development of programs

\section{Methods}

\subsection{Sampling}

This study is a survey from CIRES (centre de recherche economique et social ), CNRA (centre national de recherche agronomie) which are animated by lecture from University of FELIX HOUPHOUET BOIGNY, University of Nangui ABrogua; University of Alassane Ouattara, University of Korogho ,University of Daloa and University of MAN.The survey continued in INPHB(institut polytechinque Felix Houphouet Boigny) which constitutes a reference school in Ivory Coast.

The Survey involve a random selection from different Universities animated by lecture in social, economic, agronomic, mathematic, and technical department. We are also collected information from post gradated students, because some of them already published their first Scientific work

This survey do not anonymised the participants. We considered the position of each searcher in universities or institution. We just considered their opinions or answer which attracted our attention.

\section{Research Design}

In order to conduct our study, we developed 5 hypothesis which are questionnaire. All participants answered the questions on the subject of research paper challenges encountered by searchers.

Those hypotheses have been chose according to the previous empirical studies and based on the difficulties encountered by lecture and searchers in the country. As we know the problemes facing by High income countries are difference from less-developed countries.

The 5 hypothesis has been sent par the differences participants through social networks such as linkedln whatspp; wechat and also through mail. Participants in this survey are included research professionals, professors, Associate professor, searchers and thesis students.

\subsection{Model Specification}

The study is based on participants opinions regarding hypothesis of the research. The 5 hypothesis questions have been answered by all .participants and their opinions have been compiled, in order to reach a quantitative Analysis. As mentioned above, this study is survey on the challenges encountered by searchers during their research paper. It is based on people opinions and feeling about the research in differences fields in Cote d'ivoire. 
Participants are searcher of institutions, professor, Associate professor and post graduate students. The choice of this qualitative study is to gain holistic, comprehensive and affluent data (Walker et al. 2008). On the other hand, Qualitative study is to understand a phenomenon, and generate words, rather than numbers, as data for analysis (Patton \& Cochran, 2002).

As showed below on the table, the research established that approximately forty seven percent (45\%) of participants are Associate-searchers professors. An additional 15\% are professors and approximately forty percent (40\%) are enrolled in Post gradated Programs.

Table 1. Level of of participants

\begin{tabular}{ll}
\hline Level of Education & Percentage \\
\hline Professors & $15 \%$ \\
Associate-Searchers professor & $45 \%$ \\
Post gradued students & $40 \%$ \\
\hline
\end{tabular}

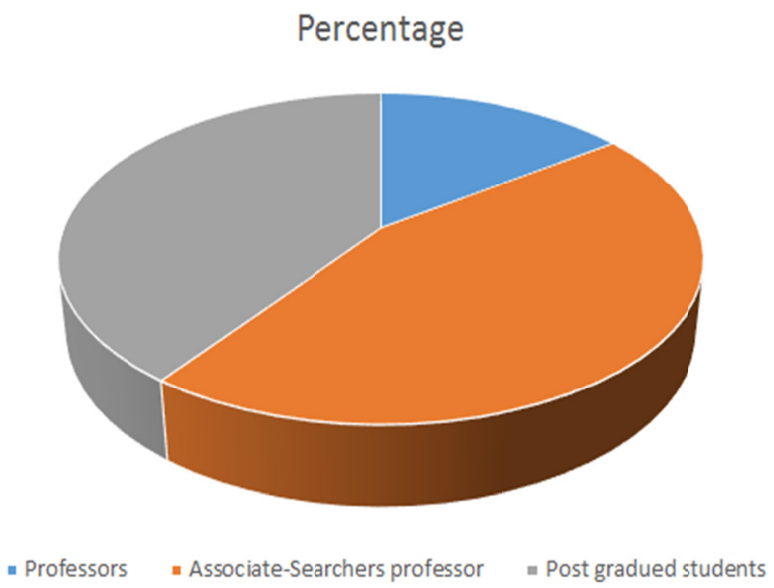

Figure 1. Level of education of participants

\subsection{Research Hypothesis}

H1: Difficulty in accessing publications during the literature review stage.

H2: Difficulty in sourcing funding, especially at the national level.

H3: Factors affecting research output in Cote d'ivoire.

H4: Facilities for research training and skill development.

\section{Result}

\section{a. Participant characteristics}

Seven Universities have been selected to animate our survey. Each university are represented by differences UFR (Training and research Unities). Participant rate of each University has been summarized in our table. The Survey has registered 212 participants' responses on the total number of 260 searchers, which is estimated at $81 \%$ as ratio.

Thus participation rate for each university is therefore described based on the University and UFR participants (Professor, associate professor and Post gradated students) that were selected to participate. The University of felix houphouet registered large number of participants response, equal to 68 searchers. It is representing $80 \%$ of participation. The University of korogho participant rate is $71 \%$ with 23 participants response. University of Daloa participant response ratio is estimated at $87 \%$ with the number of 47 participants, while with 17 participants at the university of Bouake, the ratio is $77 \%$.

INPHB school participant's ratio is $100 \%$, because the two professors interrogated in this survey did not decline. The University of NANGUI ABROGUA ratio is $80 \%$ with only 8 participants. All specifications have been 
identified by the differences searchers (professors, Associate -searchers professor and Post gradated students in each departments.

Table 2. Characteristics of participants

\begin{tabular}{|c|c|c|c|}
\hline UNIVERSITY OF FELIX HOUPHOUET BOIGNY & $\begin{array}{l}\text { Numbers } \\
\text { searchers }\end{array}$ & Number of participants & Ratio \\
\hline UFR DE MATHEMATIQUE ET INFORMATIQUE & 25 & 14 & 0.56 \\
\hline UFR DE SCIENCE DES STRUCTURES DE LA MATIERE & 15 & 15 & 1 \\
\hline UFR DES BIOSCIENCES & 25 & 22 & 0.88 \\
\hline UFR DES SCIENCES ECONOMIQUES DE GESTION & 20 & 17 & 0.85 \\
\hline total UFHB & 85 & 68 & 80 \\
\hline \multicolumn{4}{|l|}{ UNIVERSITY DE MAN } \\
\hline UFR SCIENCE ET TECHNIQUE & 15 & 12 & 0.8 \\
\hline UFR SCIENCE GEOLOGIQUE & 10 & 5 & 0.5 \\
\hline UFR INGENIERIE FORESTIERE ET ENVIRONNEMENTALE & 30 & 25 & 0.83 \\
\hline TOTAL UMAN & 55 & 42 & 76 \\
\hline \multicolumn{4}{|l|}{ UNIVERSITY JEAN LORONGNON GUEDE(DALOA) } \\
\hline UFR SCIENCE ENVIRONNEMENTALE & 20 & 19 & 0.95 \\
\hline UFR AGRONOMIQUE & 15 & 12 & 0.8 \\
\hline UFR SCIENCES ECONOMIQUES ET DE GESTION & 19 & 16 & 0.84 \\
\hline total OF UDALOA & 54 & 47 & 87 \\
\hline \multicolumn{4}{|l|}{ UNIVERSITY OF KOROGHO } \\
\hline UFR DE SCIENCE BIOLOGIQUES & 5 & 3 & 0.6 \\
\hline UFR DES SCIENCES SOCIALES & 14 & 10 & 0.71 \\
\hline INSTITUT DE GESTION AGROSPASTORALE & 13 & 10 & 0.76 \\
\hline Total & 32 & 23 & 71 \\
\hline \multicolumn{4}{|l|}{ UNIVERSITY OF BOUAKE } \\
\hline LABORATOIRE d'AGRONOMIE ET DEVPT RURALE & 10 & 5 & 0.5 \\
\hline LORATOIRE D'ANALYSE.DE MODELISATION & 5 & 5 & 1 \\
\hline ET PROSPECTIVE ECONOMIQUE & & & \\
\hline LABORATOIRE d'AGROPASTORALISME ZOOTECHNIE & 7 & 7 & 1 \\
\hline \multicolumn{4}{|l|}{ ET SANTE ANIMALE(LAZSA) } \\
\hline Total UOA & 22 & 17 & 77 \\
\hline \multicolumn{4}{|l|}{ INPHB(INSTITUT POLYTECHNIQUE FHB) } \\
\hline DEPARTEMENT DE RECHERCHE ET ECOLE DOCTORALE & 2 & 2 & 1 \\
\hline Total INPHB & 2 & 2 & 1 \\
\hline \multicolumn{4}{|l|}{ UNIVERSITY OF NANGUI ABROGUA } \\
\hline UFR SFA(Science fondementale appliquee) & 3 & 1 & 0.33 \\
\hline UFR SGE & 5 & 5 & 1 \\
\hline UFR STA( Science de la terre) & 2 & 2 & 1 \\
\hline TOTAL & 10 & 8 & 80 \\
\hline TOTAL PARTICIPANTS & 260 & 212 & 81 \\
\hline
\end{tabular}

\section{b. Difficulty in accessing publications during the literature review stage}

Participants' response regarding the Hypothesis $\mathrm{H} 1$ has been resumed in the figure 2 below. The Schema shows that $44.62 \%$ of Post gradated students' response favorably of the difficulty in accessing publications during the literature reviews stage. While only $6.92 \%$ among professors at the differences Universities supposed that access 
to publication is not easy. The $93.08 \%$ of professor responded negatively to this hypothesis. They mentioned that access to publication should not a barriers to stop achieving a scientific research. However, $17.69 \%$ of associate professor respond positively to this hypothesis. They admitted the difficulty in accessing to publications. While $30.77 \%$ of searchers confirmed the difficulty in accessing publications.

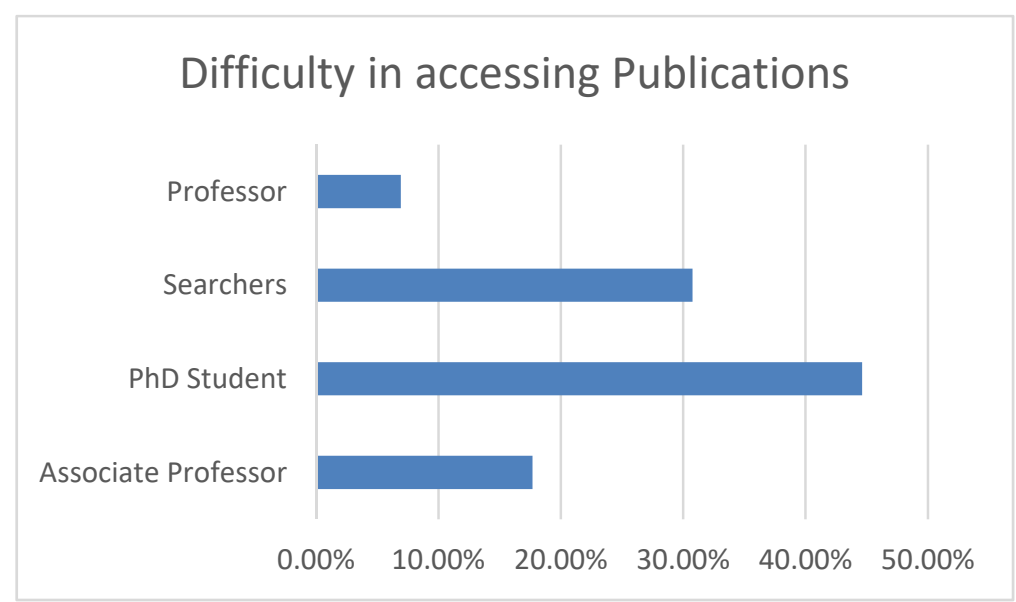

Figure 2. participants respondents, in percentage for the $\mathrm{H} 1$

\section{c. H2: Difficulty in sourcing funding, especially at the national level.}

In order to clarify the participants opinions about the difficulty in sourcing funding, the study attributed on each opinions a score variable from 50-100 points.

At 50 points level, participant score is low and express a weakness degree of difficulty to find a budget while at 100 points level, opinions indicate a strength opinion about a difficulty to find a fund to achieve a scientific research paper. Each participant chose a score to express his points of views regarding hypothesis 2 . Figure 3 expressed the participants' opinions. The study has resumed all participants opinions (Professors, Associate-professors, searchers and post gradated students) in the seven Universities mentioned above.

As result, we observed almost in each department a score above 80 points. This means searchers opinions are favorable regarding the difficulty encountered in sourcing funding. All participants are agreed and recognize the difficulty to find a budget allocate in differences field such as Biology, Agricultural, Economic, ingenerate and healthy fields.

University average score regarding the hypothesis 2 has been positive with high score of 84.5 points. In sum, participants confirmed the lack of fund to achieve a scientific research properly 


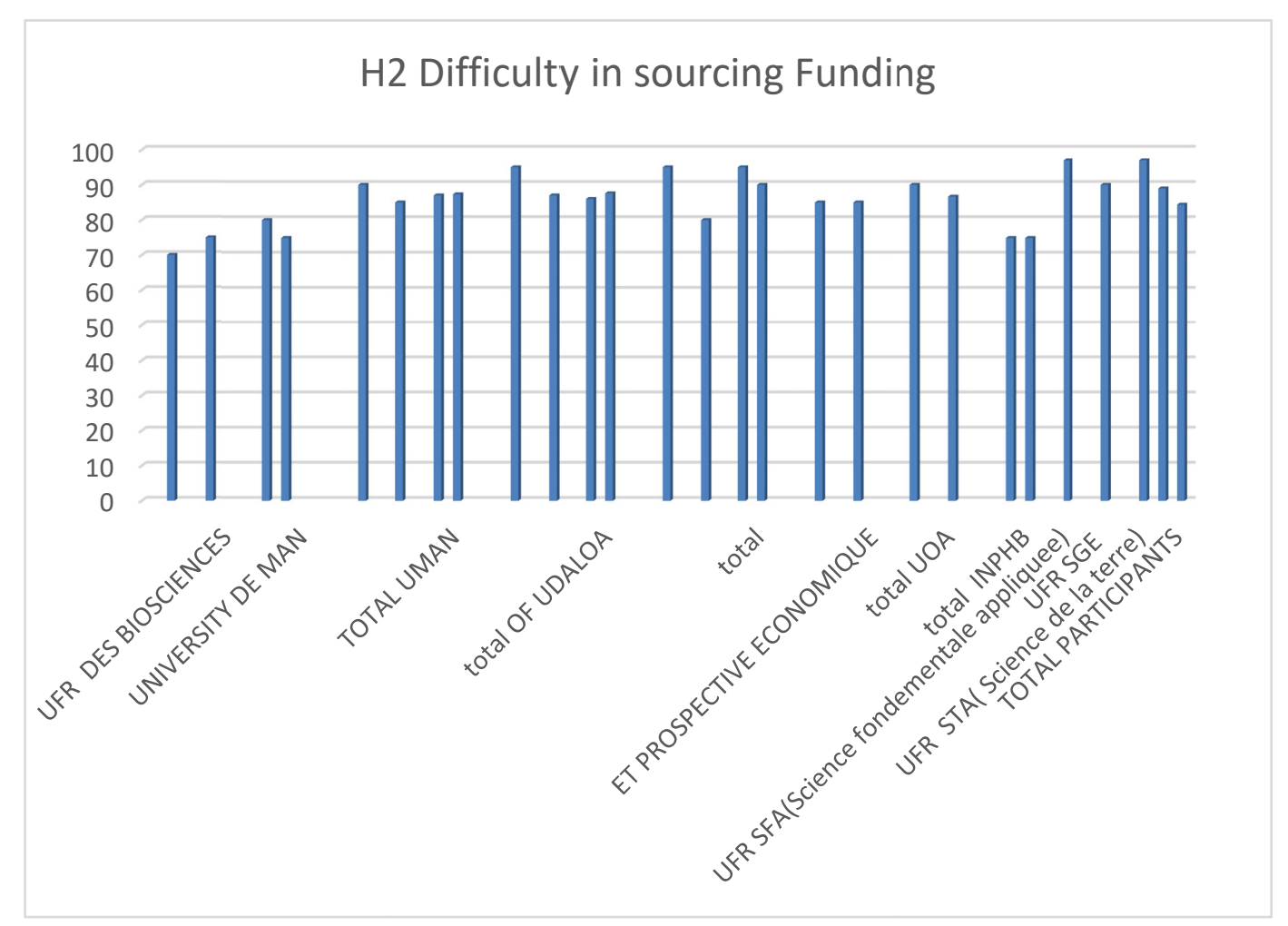

Figure 3. Difficulty in Sourcing Funding

\section{d: Factors affecting research output in Cote d'Ivoire}

Searcher from differences department of each university has underlined factors encountered and which influence research output in cote d'ivoire. Table below resumed factors listed by participants

Table3. List of factors affecting research output

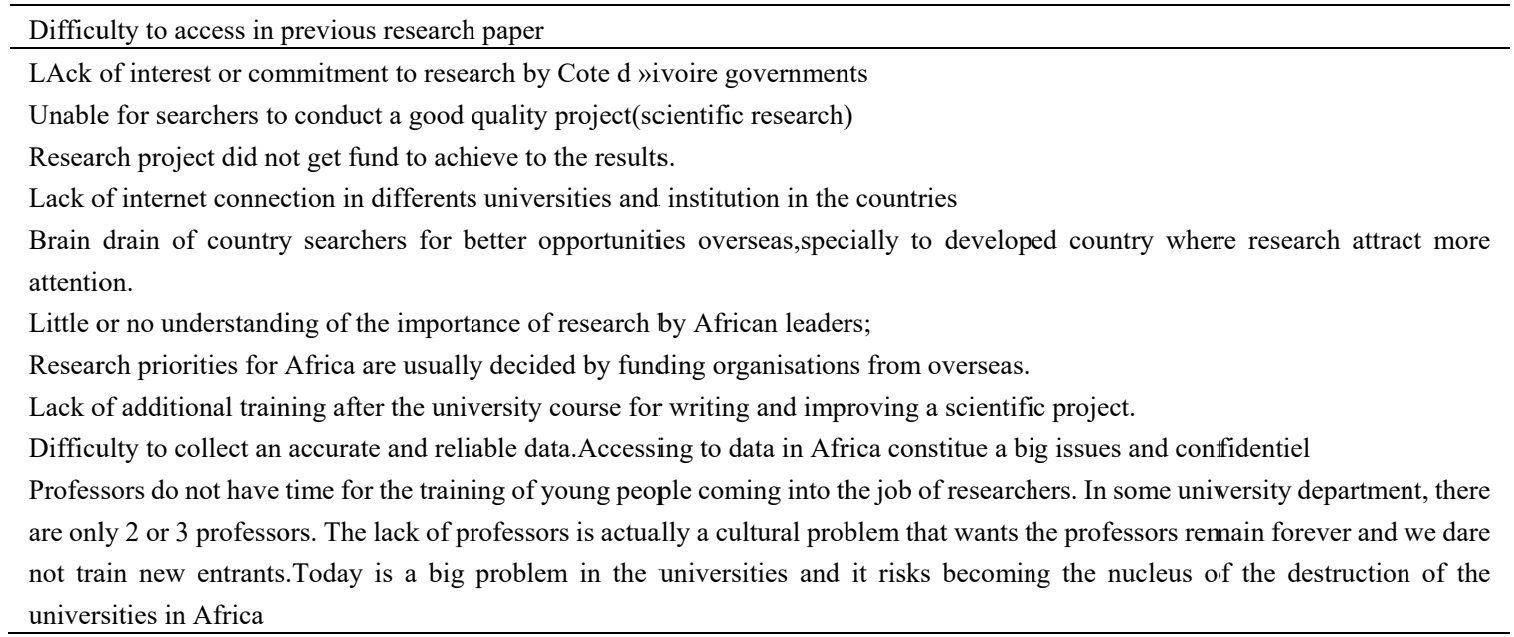

\section{$e$ : Facilities for research training and skill development}

Regard the Hypothesis 4. We asked the searchers if they knew any research institution in the country providing training and researcher development programs. Each Universities participant responded favorably.

In Cote d'ivoire there are at least three kinds of institutes operating in diversities area. There is the center and institutes attached to universities such as (Ivoirian center of research of social and economic (CIRES); Research 
institutes of mathematic (IRMA); Research institutes of ecology; Research institutes of energy fields).

The second is the center and institutes are center and institutes with dual supervision such as CNRA (national institutes of research of agronomic, Rubber harvest institutes (HEVEOGO).

Finally, the third one is the center and international institutes which are invest in different fields in the country, for instance, the center for international cooperation in agronomic research for development is a structure which accompany government in the field of agricultural.

However participants indicated that those researches institutes are not working properly because of lack of material, documents, books, internet connections and lack of training as well.

\section{Discussions}

This study has identified the key challenges encountered by searchers in the environment of universities and institutes attached to university and polytechnic school in Cote d'Ivoire. We worked with intellectual; searchers, professor, and post graduate student at different level in the country, in order to find a way to enhance, and create and generate a new scientific knowledge in the country. As we know, the scientific research is a key to the development of any country. As Cote d'Ivoire would like to be a developing country in the near future according to president vision and objective.

However, it is important that understand the development of any nation are coming from the creation of new knowledge, in order to face the environment changing due to new technology.

For the past 30 years, china has focused on creating knowledge through huge investment in research.

For instance in 2017, China's spending on research and development (R \& D) continued to grow at a brisk pace, "an official statement from the State Bureau of Chinese Statistics announced in mid-February.

On an annual basis, overall investment amounts to nearly $€ 225$ billion * (1750 billion yuan), an increase of $11.6 \%$. R \& D now represents $2.12 \%$ of the country's GDP, an increase of $0.01 \%$ compared to 2016 .

In this study, we invested on four hypothesis or variables among diversities of variables as the causes of inefficiency of scientific research achievement in the countries.

In our study, the debate of Difficulty in accessing publications during the literature review stage has been crucial. Above $65 \%$ confirmed the difficulty in accessing publication. The difficulty is coming from the lack of internet service or Wi-Fi in the campus. There is not partnership with some foreign institution online. There is not online library to upload the research paper, final thesis.

For example in Shanghai University, you can find all final thesis for PhD student in the school website. These help new comers to make their research easily. Most of Universities in China possesses library online.

Regard the hypothesis 2, we evaluate through a score The average score of participant is estimated at 84.6 points near the 100.This express the lack of fund allocate to the research fields.

Participant response matches with the figure 1 at the introduction which showed the tendency of expenditure in the education field. The GDP share allocates in education area continue to be low. Leaders do not put more attention on the education field comparing with Mauritius where

The tendency of GDP share allocate in education system continue to increase (see perspective Monde, outil pedagogue des grands tendences mondiales depuis, 1945)

None universities in cote d'Ivoire undertakes sustainability of research very seriously, comparing with British University in Egypt, where the university research plan offers mechanisms for availability of resources, environment and policies to researchers.

The lack of funding support can be the fact that members of government and higher civil servants are mostly non-scientists and it is necessary for scientists to go out and explain the significance of their work and what they hope to achieve, with the objective of building up a climate of support.

Having obtained support then the work should be pursued with the serious intention of showing results for the money received. The reason that the governments of many less-developed countries do not support scientific research more enthusiastically than they do, is because they regard research as a sack into which money is poured and nothing of apparent value comes out.

It is inevitable, probably desirable, that most research in less-developed countries will be applied or mission-oriented. Applied research need not really be restrictive -there is always room for original and basic approaches within the framework of programs having ultimate practical objectives. Such an approach is more 
likely to receive increased government funding than programs not linked to practical requirements

When it comes to the factors affecting research output and the facilities for research training and skill development in Cote d'ivoire, the challenges .is coming from the incapacity of individual researchers, including lack of skills, incompetencies and attitudes to make a quality research.

To solve these issues, it is crucial to build a research institution coupled by government support.

This will reinforce the searchers skills through organized training programs and research activities. Most of the searchers in the countries obtained their training during their Post gradated Program at University. However, this university education is not enough to develop good searcher skills. The majority of participants were agreed in added research training to complete their academic studies in on research institution..

Thus, without institutions with adequate systems for training, guidance and supervision, it is impossible for researchers to develop the skills and expertise required to produce and publish good quality research. It is therefore imperative that African universities become more research-intensive

\section{Conclusion}

The study identified the key challenge encountered by the searchers in Cote d'Ivoire during their researches to produce a quality scientific work. The studies retained four main hypotheses among varieties of challenges encountered by searcher around the world. In Cote d'Ivoire, searchers are experiencing the lack of training in research institutions as many West Africans countries, after their universities curses.

The difficulties in sourcing funding has been the key challenges encountered in cote d'Ivoire and the problems underlined is the lack of will for the leader to give a priority to education field. Scientific Research Issues in Cote d'Ivoire remain unmet and as consequence, after 59 years of independency, we still Less-developed and the budget allocated to the research remain insufficient.

The country Universities lack a minimum infrastructure to assure a good quality education. Research platform is almost in existing, due to lack of internet connection and Wi-Fi.

As consequence, we are seeing a deteriorating research quality on the country in different fields Such as medicine, economic, energy sector.

However effort has been in agricultural sector where CNRA (centre de recherche Agronomie) is performed well, in term of research in the country export products such as cocoa, coffee, cotton. But we also need government intervention effort in different areas, in order to assure our development.

Recently, in West Africa, it was found that most Ebola research has been conducted in America, while the disease remained in the continent

As consequence of lack of vigorous and high quality scientific research several issues solution in Africa remain unmet, such as, diseases may continue to resurface in Africa, standard of living depreciated, death rates multiplied and the African continent will remain under-developed.

\section{References}

Anson, R., \& Smith, K. (2004). Undergraduate Research Projects and Dissertations: issues of Topic Selection, Access and Data Collection Amongst Tourism Management Students. Retrieved January 17, 2009 from http://www.hist.ltsn.ac.uk/johiste

Burke, J., Anthony, J. O., \& Lisa, A. T. (2007). Toward a Definition of Mixed Methods Research, University of Albana.

Çilsalar, H. (2011). The profile of tutors of Erciyes University. Master Thesis, Erciyes University Institute of Educational Sciences, Turkey.

Creswell, J. W. (2003). Research Design: Qualitative, Quantitative and Mixed Methods Approaches (2nd ed.). London: Sage Publications.

Erdem, A. R. (2008). Are academic members academics? Is he a scientist? Journal of Academic Design, 2(2), 83-85.

Ertekin, C., Berker, N., Tolun, A., Ülkü, D., Aksan, D., Erzan, A., Güriz, A., \& Öztürk, O. (2002). Ethics and problems in scientific research. Ankara: Turkish Academy of Sciences Publications.

Jouanjean, B. (2019). The evolution of scientific medical research gives medical prevention a global and universal status. 
Khan J. (2015). The Role of Research and Development in Economic Growth: A Review. J Econ Bibliogr, 2 , 128-33. http://www.kspjournals.org/index.php/JEB/article/view/480. Accessed 25 Sep 2018

Kumwenda, S., Niang, E. H. A., Orondo, P. W., William, P., Oyinlola, L., Bongo, G. N., \& Chiwona, B. (2017). Challenges facing young African scientists in their research careers: A qualitative exploratory study. Malawi Medical Journal, 29(1).

Morse, J. M., \& Richards, L. (2002). Readme First for a User's Guide to Qualitative Methods. Thousand Oaks, CA: Sage Publications.

Nasuirma, D. K. (2000). Survey sampling theory and methods. Nairobi: University of Nairobi press.

Neumann, W. L. (2000). Social research methods: qualitative and quantitative approaches. Boston:

Öztürk, F., \& Bayrak, T. (2015). The academicians' perspective on the challenges facing higher education in Turkey. World Conference on Technology, Innovation and Entrepreneurship, 195, 202-209.

Time Management for Students. (2008). Retrieved October 15, 2008 from http://www.pleasval.k12.ia.us/ studyskills/studenttimemanagement.htm

\section{Copyrights}

Copyright for this article is retained by the author(s), with first publication rights granted to the journal.

This is an open-access article distributed under the terms and conditions of the Creative Commons Attribution license (http://creativecommons.org/licenses/by/4.0/). 